\title{
Physical Education Major's Knowledge of Appropriate Instructional Practices in Middle School Physical Education 在中學體育教學實践：通當的體育教育專業學生知識
}

\author{
David BARNEY \\ Brigham Young University, U.S.A \\ Robert CHRISTENSON \\ Oklahoma State University, U.S.A
}

Frank PLEBAN

College of Health Sciences, Murray State University, U.S.A.

\begin{abstract}
For many years students have been exposed to inappropriate instructional practices in physical education, resulting in bad experiences and inadequate learning. Introducing pre service physical education (PE) majors to Appropriate Instructional Practices (AIP) is a recommended method of preparation. Unfortunately, many PE majors have been exposed to inappropriate instructional practice; thus they perceive those practices as appropriate to use in their teaching. To determine PE majors' understanding of AIP, 313 PE majors (161 males \& 152 females) from 7 different institutions participated in this study. Based on incorrect responses it was found that PE majors believed that organizing students in large group for activities was an appropriate instructional practice. In addition, results demonstrated that PE majors thought students should be graded for wearing prescribed clothing in class and be required to sit out if not dressed appropriately. With these results PETE faculties have a great opportunity and have a better understanding of preparing their PE majors in appropriate instructional practices.
\end{abstract}

\section{摘 要}

如果學生接觸到不恰當的體育教學, 容易造成不好的經驗和學習的不足。本文邀請313體育本科生（男161，女152）參加了 這項研究。結果表明, 體育本科生認為需要分級穿著規定體育服裝, 以及理解他們體育專業的教學實践。

\section{Introduction}

In physical education (PE) classes, it is anticipated that the students will enjoy participating in physical activities. It is also hoped student participation will lead to a lifetime of physical activity. Unfortunately, this has not always been the case. Rice (1988) found that students felt PE was boring, unnecessary, a waste of time, or not cool. In another study Scantling, Strand, Lackey, and McAleese (1995) found that high school students did not take PE class because; (a) students did the same things over and over, (b) showering was a hassle, (c) males tended to dominate in class activities, and (d) too much emphasis on winning and losing.

One of the reasons students may not enjoyed their PE experience is the fact that the PE teacher does not use appropriate instructional strategies during lessons or activities. For example, students may have participated in a wide range of inappropriate games, such as dodge 
ball \& duck-duck goose (Williams, 1992), or could have experienced captains picking teams in front of the whole class (Williams, 1996). Students may have participated in a skill activity where there was one ball for the whole group or they may have had to stand in long lines for their turn to complete the task.

With inappropriate instructional practices documented, there are appropriate instructional practices that are taking place in physical education classes at all levels. For example, curriculums include team and individual sports, dance, rhythmic movement, cooperative and competitive activities, fitness and outdoor pursuits (Bibik, Stephen \& Omega-Smith, 2007) and discipline within the class is fair and consistent and encourage students to be responsible for their own behavior (Pangrazi, 2007).

Research is evident regarding the awareness of appropriate instructional practices (AIP) in PE. For example, Barney and Strand (2008) studied high school students' knowledge of AIP. It was found that high school students felt it was appropriate for students in class to serve as team captains and pick teams before the entire class, and to be graded on attendance and dressing in proper attire for class activities. Another study looked at parents' knowledge of AIP in elementary physical education (Barney \& Pleban, 2010). Parents thought that students should get awards for reaching a certain level of fitness in national or state fitness tests. Also, parents believed that dodge ball was an appropriate PE activity for elementary aged students. One last study investigated PETE majors' knowledge of AIP in elementary physical education (Barney \& Christenson, 2013). PETE majors felt that students should be graded on dress, attendance and effort during class activities, and that dodge ball was an appropriate for elementary aged students.

Preconceived notions of inappropriate or appropriate instructional practices by PETE majors may be due to the experiences they were exposed to as students during their K-12 physical education classes (Doolittle, Dodds \& Placek, 1983). Lawson's (1983) conceptual framework of subjective warrant, which states that a student's perceptions of the requirements for teacher education and for actual teaching in schools will be affected by their past PE experiences. Based on socialization factors in PE, there is a greater likelihood that PE majors will teach how they were taught. As part of PETE programs, it is not only important to expose PETE majors to appropriate instructional practices throughout their program of study, it is also critical that PETE faculty have an understanding of the preset ideas students have as they enter the program. Thus, the purpose of the study was to gain knowledge of what PETE majors know about appropriate instructional practices in middle school physical education.

\section{Methods}

\section{Participants \& Setting}

Participants for this study were 313 PETE majors (161 males \& 152 females) from seven universities in the United States. Three universities were from the south and four located west of the Rockies. The universities in this study were considered land grant, regional and private universities. Institutional Review Boards (IRB) from each university granted approval to conduct this study. The participants were all enrolled in an introduction to physical education course or equivalent at their respective universities. The researchers chose this population because the introduction to physical education class is usually the first major course PETE majors take in their program of study. As such, many PETE majors have not been exposed to AIP in physical education; thus, their current knowledge of what is considered appropriate practice in physical education pedagogy is largely based on previous experience.

\section{Instrumentation}

For this study, the researchers used a survey that was created and used in previous research dealing with AIP in middle school physical education (Barney, Strand, \& Prusak, 2013). The Middle School Physical Education Appropriate Practice Survey (MSPEAP; Table 1) is a 24-statement survey that has four general areas of interest: (a) Curriculum (seven statements; 1, 2, 3, 4, 5, 6, 23), (b) Instructional Strategies (seven statements; 13, 14, 15, 18, 19, 21, 22), (c) Learning Environment (eight statements; 7, 8, 9, 10, 11, 12, 17, 24), and (d) Assessment (two statements; 16, 20). Approximately one half of the survey statements reflected appropriate instructional practices and the other half inappropriate instructional practices. 


\section{Table 1. Middle School Physical Education Appropriate Practice Survey.}

Please indicate your belief regarding each of the following statements by circling A, if you agree that the practice is appropriate or D if you do not agree that the practice is appropriate.
A D
1. The curriculum should include team and individual sports, dance, and rhythmic movement, cooperative and competitive activities, fitness and outdoor pursuits, and those activities involving positive risk-taking experiences.

A D 2. Lessons are planned so that students learn skills safely and efficiently.

A D 3. The teacher exposes students to a variety of activities in short units.

A D 4. Teachers organize activities involving large groups or regulation-sized teams.

A D 5. Games and activities should allow students to apply learned skills in real life situations.

A D 6. Teachers select human target games and drills that allow aggressive behaviors towards other students in the class.

A D 7. Learning experiences are designed to help and encourage students to communicate with others, accept individual strengths and differences, and cooperate to solve problems.

A D 8. Teachers should help students understand competition with inanimate objects, competition against a record, or competition against a previous performance. That competition does not have to be against a team or individual.

A D 9. Groups or teams may be formed by student "captains" publicly selecting one child at a time, sometimes with a system of alternating gender.

A D 10. Feedback of skill performance should come from a variety of sources including the teacher, peers, videotaping or self-analysis.

A D

11. Discipline within the class should be fair and consistent and encourage students to be responsible for their own behavior.

A D 12. Students may be permitted to make negative or sarcastic comments about individuals or groups in the class.

13. Teachers allow students guided choices in matters such as equipment, modification of rules, or types of skill practice (e.g., completing individual task sheets or small group instruction).

14. Teachers should require all students to do the same activity with no accommodations made for skill and fitness differences or student interest.

15. All students should do the same warm-up exercises regardless of their fitness levels.

16. Students are graded on wearing prescribed clothing and are restricted from participation based on dress.

17. Exercise may be used as punishment for student misbehavior in class.

18. Teachers should provide students with experiences that encourage students to apply, analyze and evaluate various concepts related to motor skills.

19. Teachers should target students fitness areas for weakness and plan appropriate activities to improve student fitness.

20. Teachers should use the information gathered from assessment to diagnose those areas requiring further instruction as they plan future lessons.

21. Outside of class assignments should give students a chance to practice and apply information introduced in physical education class.

A D 22. Teachers should introduce and expose students to such technology as pedometers, heart rate monitors and current software programs. planning lessons in physical education

A D 24. Students should supervise/monitor high-risk stations or activities during class. 


\section{Procedures}

Researchers contacted PETE faculty at seven institutions of higher education by phone and explained the purpose of the study. Seven PETE faculty (6 males and 1 female), averaged 10 years of teaching in higher education, agreed to ask their students to participate in the study. The faculty member at each institution took five minutes at the beginning of their class to explain the study and ask for volunteers. Volunteers read, signed and returned and informed consent form before anonymously completing the survey. Students were assured that nonparticipation or withdrawal from the study would not negatively affect their grade in their introduction to physical education class. After the surveys were completed, the PETE faculty member mailed the surveys back to the researchers. The results for this study are reported as percentages. A review of the literature identified an instrument related to appropriate instructional practices in middle school PE. The instrument was used to assess middle school student's knowledge of appropriate instructional practices in middle school PE (Barney, Strand, \& Prusak, 2013). The instrument is a 24-item survey. In the named study, the survey was pilot tested and was determined to be valid and reliable.

\section{Results}

Table 2 reveals four of the 24 statements were incorrectly identified by a majority of male and female PETE majors as appropriate or inappropriate instructional practices in PE. The results pertinent to each of the four general areas (curriculum, instructional strategies, learning environment, and assessment) are further discussed.

Table 2. Results Regarding PETE Majors Knowledge of Appropriate Instructional Practices in Middle School Physical Education.

\begin{tabular}{|c|c|c|c|c|c|c|}
\hline \multirow[t]{2}{*}{ Question } & \multicolumn{2}{|c|}{ Total Population } & \multicolumn{2}{|c|}{ Male } & \multicolumn{2}{|c|}{ Female } \\
\hline & Agree & Disagree & Agree & Disagree & Agree & Disagree \\
\hline 1 & $94 \%$ & $7 \%$ & $95 \%$ & $5 \%$ & $94 \%$ & $7 \%$ \\
\hline 2 & $97 \%$ & $3 \%$ & $95 \%$ & $5 \%$ & $99 \%$ & $1 \%$ \\
\hline 3 & $89 \%$ & $11 \%$ & $88 \%$ & $12 \%$ & $90 \%$ & $10 \%$ \\
\hline 4 & $80 \%$ & $20 \%$ & $83 \%$ & $17 \%$ & $78 \%$ & $22 \%$ \\
\hline 5 & $93 \%$ & $7 \%$ & $91 \%$ & $9 \%$ & $95 \%$ & $5 \%$ \\
\hline 6 & $14 \%$ & $86 \%$ & $21 \%$ & $79 \%$ & $5 \%$ & $95 \%$ \\
\hline 7 & $94 \%$ & $6 \%$ & $90 \%$ & $10 \%$ & $99 \%$ & $1 \%$ \\
\hline 8 & $82 \%$ & $18 \%$ & $81 \%$ & $19 \%$ & $84 \%$ & $16 \%$ \\
\hline 9 & $38 \%$ & $62 \%$ & $48 \%$ & $52 \%$ & $27 \%$ & $73 \%$ \\
\hline 10 & $82 \%$ & $18 \%$ & $82 \%$ & $18 \%$ & $82 \%$ & $18 \%$ \\
\hline 11 & $94 \%$ & $6 \%$ & $92 \%$ & $8 \%$ & $96 \%$ & $4 \%$ \\
\hline 12 & $12 \%$ & $88 \%$ & $17 \%$ & $83 \%$ & $6 \%$ & $94 \%$ \\
\hline 13 & $76 \%$ & $14 \%$ & $72 \%$ & $28 \%$ & $80 \%$ & $20 \%$ \\
\hline 14 & $32 \%$ & $68 \%$ & $39 \%$ & $61 \%$ & $24 \%$ & $76 \%$ \\
\hline 15 & $62 \%$ & $38 \%$ & $68 \%$ & $32 \%$ & $54 \%$ & $46 \%$ \\
\hline 16 & $63 \%$ & $37 \%$ & $67 \%$ & $33 \%$ & $59 \%$ & $41 \%$ \\
\hline 17 & $31 \%$ & $69 \%$ & $37 \%$ & $63 \%$ & $24 \%$ & $76 \%$ \\
\hline 18 & $95 \%$ & $5 \%$ & $93 \%$ & $7 \%$ & $97 \%$ & $3 \%$ \\
\hline 19 & $91 \%$ & $9 \%$ & $90 \%$ & $10 \%$ & $93 \%$ & $7 \%$ \\
\hline 20 & $95 \%$ & $5 \%$ & $92 \%$ & $8 \%$ & $98 \%$ & $2 \%$ \\
\hline 21 & $86 \%$ & $14 \%$ & $83 \%$ & $17 \%$ & $91 \%$ & $9 \%$ \\
\hline 22 & $82 \%$ & $18 \%$ & $75 \%$ & $25 \%$ & $90 \%$ & $10 \%$ \\
\hline 23 & $68 \%$ & $32 \%$ & $62 \%$ & $38 \%$ & $76 \%$ & $24 \%$ \\
\hline 24 & $53 \%$ & $47 \%$ & $61 \%$ & $39 \%$ & $44 \%$ & $56 \%$ \\
\hline
\end{tabular}




\section{Curriculum}

A majority of male and female majors incorrectly identified one curriculum statement as appropriate. Teachers organize activities involving large groups or regulation-sized teams. The data revealed that $83 \%(\mathrm{n}=133)$ of the male and $78 \%$ ( $\mathrm{n}=118$ ) of the female PETE majors felt it was appropriate for teachers to organize activities involving large groups or regulation-sized teams.

\section{Instructional Strategies}

The PETE majors incorrectly answered one statement under the area of instructional strategies: All students should do the same warm-up exercises regardless of their fitness levels. Sixty-eight percent $(\mathrm{n}=109)$ of the males and $54 \%(\mathrm{n}=82)$ of females felt that all students should do the same warm-up exercise regardless of their fitness levels.

\section{Learning Environment}

The data from the learning environment category also found one statement incorrectly identified by the male PETE majors. The statement that was incorrectly answered was statement 24, which states, Students should supervise/monitor high-risk stations or activities during class. For this statement, $61 \%(\mathrm{n}=98)$ of the male PETE majors felt this was an appropriate practice, yet, 56\% $(n=85)$ of the female PETE majors correctly answered this statement.

\section{Assessment}

One statement was incorrectly identified under the assessment section: Students are graded on wearing prescribed clothing and are restricted from participation based on dress. The data disclosed that $67 \%(\mathrm{n}=107)$ of male and 59\% ( $n=89)$ of the female PETE majors incorrectly answered this survey statement.

One last concluding insight regarding the data came from statement nine, which states, Groups or teams may be formed by student "captains" publicly selecting one child at a time, sometimes with a system of alternating gender. Even though there wasn't a majority of PETE students incorrectly answering this statement, $48 \% \quad(n=77)$ of the male PETE students felt that picking teams in front of the whole class was an appropriate instructional practice. For the female PETE students, 73\% ( $n=110)$ felt it was an inappropriate practice.

\section{Discussion}

The purpose of this study was to gain knowledge of what PETE majors know about appropriate instructional practices in middle school physical education. The results from this study were encouraging for the fact that both male and female PETE majors correctly identified 20 of the 24 survey statements. Yet, there were four statements that were incorrectly answered that need to be addressed.

One of the first items that the PETE majors incorrectly answered dealt with teachers organizing students in large groups or regulation-sized teams to participate in an activity (statement four). Bell, Johnson, Shimon, and Bale (2013) studied the effects of students participating in small (3v3), medium (6v6) and largesided (12v12) throwing and catching (ball touches) games for 10-11 year elementary aged students. The researcher found that students that who participated in $3 \mathrm{v} 3$ and $6 \mathrm{v} 6$ games had more ball touches than in the $12 \mathrm{v} 12$ games. The researchers concluded that the students that who participated in the $3 \mathrm{v} 3$ and $6 \mathrm{v} 6$ were more engaged in the game, which affected their participation levels. The results from this study concur with Pangrazi's (2007) thoughts regarding students having a piece of equipment. He said that students learn more when they all have their own equipment (ball, hoop, beanbag, etc.) and space to participate. When every student has their own equipment, they focus better on the task at hand, thus reducing offtask behavior. Placing students into large-sized games also sets the stage for problems such as misbehavior, inattention, general apathy and lower activity levels (McCormick, Hannon, Newton, Shultz, Miller, \& Young, 2012).

The second item PETE majors incorrectly answered dealt with students doing the same warm-up exercises regardless of their fitness levels (statement 15). Rikard and Banville (2006) studied high school student attitudes towards physical education. These high school students disliked fitness activities as being due to the limited and dull choices of running activities. For many students, fitness consists of running laps or the same activities, with no variety offered to students. The researchers continued by stating that fitness-based activities are essential to the purpose of physical education but militaristic fitness and basic running around the track activities must be abandoned and be replaced with positive motivating fitness activities that students will enjoy, learn and get the benefits from fitness activities. 
Third survey statement dealt with students being graded on wearing prescribed clothing and if not wearing the right clothing it will affect their participation in class (Statement 16). This question really discusses two inappropriate instructional practices. Miller (2002) has stated that basing grades on students dressing in PE attire, and for this study, prescribed attire, undermines physical education and the true purposes of physical education class. Teachers should explore a variety of alternative assessment techniques to analyze students' learning and the teacher effectiveness (Barney \& Strand, 2006).

The second part of this survey statement also alluded to implementing an inappropriate instructional practice of prohibiting students from participating in $\mathrm{PE}$ if they did not wear the proper clothing they cannot participate in class activity. One of physical education's main tenants is for students to come to class and participate and learn skills that will aid them throughout their lives. For middle school students, physical education is a positive and enjoyable class period in their day (Ryan, Fleming \& Maina, 2003). Yet, when middle school physical educators have students sit out due to inappropriate attire, there is the possibility of negatively affecting their attitudes towards their physical education class and even affecting them being physically active throughout their life.

A fourth survey statement incorrectly answered by the male PETE students was having students supervising or monitoring high-risk stations or activities during class (Statement 24). Physical educators should be wise enough to know that they should not plan activities that would put students in a position to be hurt or hurt others. Also, physical educators should be smart enough to know that there are liability issues they should be aware of regarding their students. Physical educators need to keep in mind what is best for the students, not the teacher (Prusak \& Vincent, 2005).

One final point that needs to be addressed dealt with the grouping of students or captains picking teams in front of the whole class (Statement 9). Over 73\% of the female PETE majors found this instructional practice inappropriate. This is encouraging, yet $48 \%$ of the male PETE majors felt this was an appropriate instructional practice to use in physical education class. Forty-eight percent is not a majority; still almost half of the male PETE students found this an appropriate practice. It is the researchers opinion that many of these PETE majors participated in this practice while they were in their physical education classes. And while this practice was going on, these PETE majors were probably the first students picked or were the captains picking the teams. In their minds they saw nothing wrong with this instructional practice. Yet for those students who were not the captains picking the teams, or worse still the last ones picked to be on a team it is no fun and not good for that student. This is the kind of instructional practices that can have negative and lasting effects on students. It could affect attitudes towards physical education class, physical activity, and eventual physical activity throughout life. With the findings from this study, Barney and Strand (2006) feel that the PETE programs, or the preparation of PE teachers are a good starting point to teach and implement appropriate instructional practices in $\mathrm{PE}$.

\section{Implications for PETE Faculty}

PETE faculty have a big responsibility in preparing quality PETE majors. As good as this may be in theory, there are challenges PETE faculties will face in their preparations of these PE majors. Lawson's (1983) conceptual framework of subjective warrant will have to be confronted by PETE faculties. The conceptual framework of subjective warrant consists of a person's perceptions of the requirements for teacher education and for actual teaching in schools. This results from years of socialization in the physical education setting. The PE majors have spent many hours in school gymnasiums and playing fields, in contact with PE's subject matter and teachers have provided opportunities for a subjective warrant to be formed. Many of these PETE majors have taken PE classes for approximately 12 years and have observed and participated in physical education from many different physical educators, thus, their attitudes and opinions of how to teach physical education may have been influenced by those experiences. Those experiences often guide their perception of how physical education classes should be taught.

PETE faculty have their work cut out for them. Teacher preparation programs are the first link in improving the quality of physical education as a whole, and teacher preparations programs should include the NASPE appropriate practices document in their courses of study (Barney \& Strand, 2006). When middle school physical educators implement appropriate instructional practices in their teaching they have the opportunity 
to educate the whole student in the three domains: psychomotor, cognitive and affective. When middle school students have positive experiences in their physical education classes, the consequences will be lifelong towards the positive.

\section{References}

Barney, D., \& Christenson, R. (2013). Do physical education majors know what instructional practices are appropriate in elementary physical education. The Global Journal of Health and Physical Education Pedagogy, 2, (1), 17-29.

Barney, D., \& Pleban, F. (2010). Parents knowledge of appropriate teaching practices in elementary school physical education. International Journal About Parents in Education, 4, (1), 1-10.

Barney, D., \& Strand, B. (2006). Appropriate practices in elementary physical education: Create a foundation for physical education majors. Teaching Elementary Physical Education, 17, 20-23.

Barney, D., \& Strand, B. (2008). Do high school students' know what practices are appropriate in physical education. The High School Journal, 92, 3340.

Barney, D., Strand, B, \& Prusak, K. (2013). Middle grade students' knowledge of appropriate instructional practices in PE. The Global Journal of Health and Physical Education Pedagogy, 2, 165-176.

Bell, K. A., Johnson, T. G., Shimon, J., \& Bale, J. (2013). The effects of game size on the physical activity levels and ball touches of elementary school children in physical education. Journal of Kinesiology and Wellness, 2, 13-19.

Bibik, J.M., Goodwin, S.C., \& Omega-Smith, E.M. (2007). High school students attitudes towards physical education in delaware. The Physical Educator, 64, 192-204.

Doolittle, S., Dodds, P., \& Placek, J. (1983). Persistence of beliefs about teaching during formal training of preservice teachers. Journal of Teaching in Physical Education, 12, 355-365.

Lawson, H. (1983). Toward a model of teacher socialization in physical education: The subjective warrant, recruitment, and teacher education. Journal of Teaching in Physical Education, 2, 3-16.
McCormick, B.T., Hannon, J.C., Newton, M., Shultz, B., Miller, N., \& Young, W. (2012). Comparison of physical activity in small-sided basketball games versus full-sided games. International Journal of Sports Science \& Coaching, 7, 192-204.

Miller, D. K. (2002). Measurement by the physical educator: Why and how. Boston, MA: McGraw-Hill.

Pangrazi, R. P. (2007). Dynamic physical education for elementary school children (15th ed.). San Francisco, CA: Benjamin Cummings.

Prusak, K. \& Vincent, S. (2005). Is your class about something? Guiding principles for physical education teachers. Journal of Physical Education, Recreation and Dance, 76, (6), 25-28, 35.

Rice, P. L . (1988). Attitudes of high school students towards physical education activities, teachers, and personal health. The Physical Educator, 45, 94-99.

Rikard, G. L. \& Banville, D. (2006). High school student attitudes about physical education. Sport, Education and Society, 11, (4), 385-400.

Ryan, S., Fleming, D., \& Maina, M. (2003). Attitudes of middle school students towards their physical education teachers and classes. The Physical Educator, $60,28-42$.

Scantling, E., Strand, B., Lackey, D., \& McAleese, W. (1995). An analysis of physical education avoidance. The Physical Educator, 52, 197-202.

Williams, N. F. (1992). The physical education hall of shame. Journal of Physical Education, Recreation and Dance, 63, 57-60.

Williams, N. F. (1996). Inappropriate teaching practices. Journal of Physical Education, Recreation and Dance, 67, 45-49.

\section{Correspondence}

David Barney, Ed.D.

Brigham Young University

249 G SFH Provo, Utah 84602, USA.

Phone: (801) 422-6477

Email: David_Barney@byu.edu 